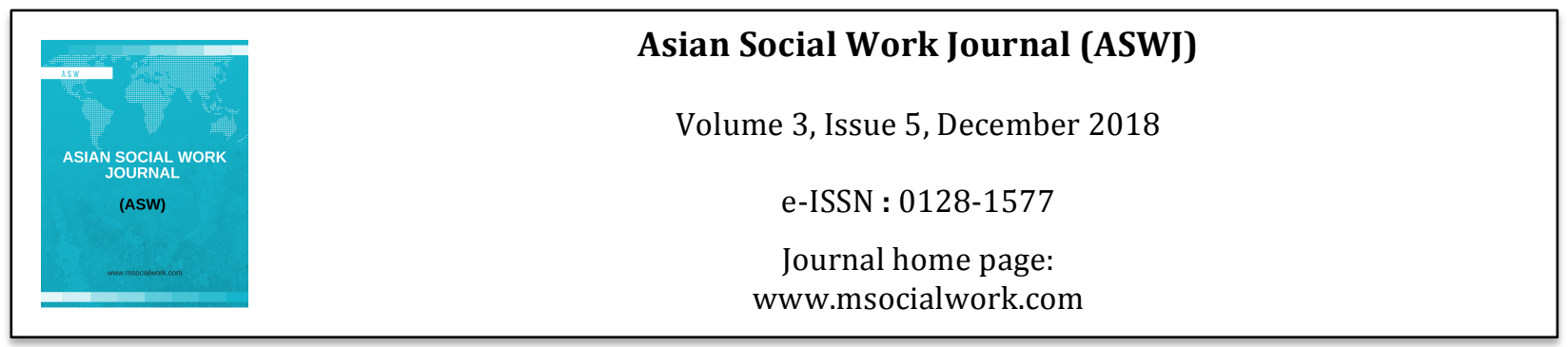

\title{
Poverty Alleviation Policy in West Java Province
}

\author{
Siti Anah Kunyati ${ }^{1}$, Didiet Widiowati ${ }^{2}$ \\ 1 UNLA \\ 2STKS
}

Corrrespondence: Siti Anah Kunyati (sitianahkunyati@gmail.com)

\begin{abstract}
Poverty and social welfare issues show an increase over time, both in the number, and the quality. On the other hand, the policy responses to social welfare issues from various parties are not sufficient to tackle those problems. This study aims to describe poverty and policy of West Java Provincial Government in poverty alleviation. The research is expected to contribute to the improvement of policy in poverty alleviation and affect the condition of West Java society to be more prosperous. The research design is Qualitative Descriptive. The informants are several Civil State Apparatuses who are capable to represent Regional Work Unit/ Organization at the provincial level. Data Collecting Techniques consist of interviews, focus group discussions, and documentation studies. Data Validation is done using triangulation between data sources and techniques. The results showed that West Java's economy grew on average above $5 \%$, while the average poverty reduction rate was only $0.46 \%$ per year. These conditions have an impact on the increased number of people who are below the poverty threshold and also affect the index of depth and severity of poverty. The situation is similar for other social welfare issues, such as socio-economic vulnerable groups, homeless, beggars, and scavengers, neglected elderly, and children who need social protection. To overcome those problems, several policies have been prepared. The obstacle is, social welfare planning and policy are often only viewed as a complement to development planning and policy framework when they should be considered as an integrative, priority and substantive element that must be implemented. Various regulations and policies on poverty alleviation and other social welfare issues are still limited. Regulation at the central level is sufficient, but local governments have not been fully able to describe and operationalize it with various rules, either at the level of Regional Regulation, Governor Regulation, Mayor Regulation, or Regent Regulation. Legislation regulation and poverty alleviation are government's (central and local) full responsibility, so coordination and a common commitment are needed to address poverty and increase equity. West Java Provincial Policy needs to prioritize efforts to increase funding through funding synergies with central and district / city governments in order to finance more comprehensive and broader poverty reduction programs.
\end{abstract}

Key words: poverty, social welfare issues, social welfare policies

\section{Introduction}

The problem of poverty is still a formidable challenge for West Java Provincial Government. This is reflected in the very low decline of poverty every year for the last 10 years, whereas West Java's relatively high economic growth is always above the national level. This development paradox is illustrated in Figure 1. 


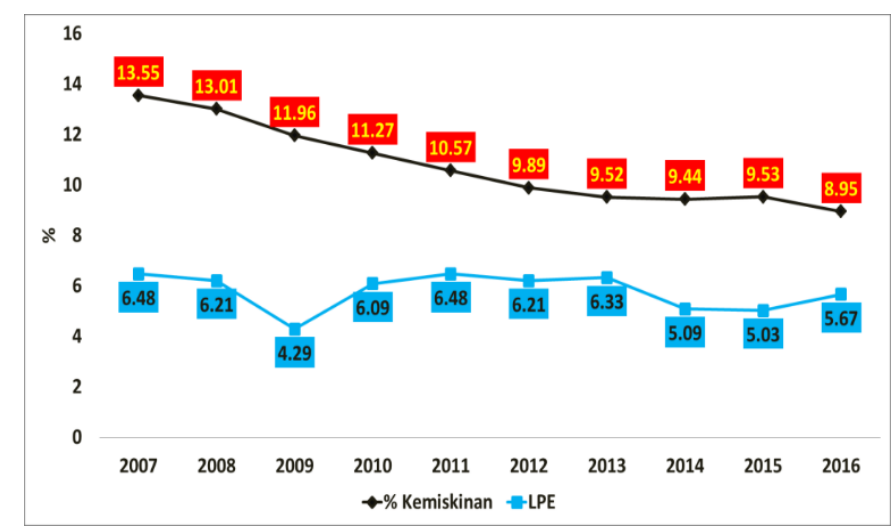

The economy grew on average above $5 \%$. The average poverty rate decline is only $0.46 \%$ per year. The logic of growing economics is not identical with the increase in people's income. To reduce poverty, a multi-dimensional development approach is needed. The state can not only rely on the development of the economic dimension but also must pay attention to the development of social welfare. Data on Social Welfare Problems shows that the phenomenon of poverty tends to increase, both in terms of number and quality of problems. On the other hand, the policy response to social welfare issues from various parties is not sufficient.

BAPPENAS (2016) considers this to be due to the limited funding priority for social protection programs. Whereas in the legislation, poverty alleviation is fully responsible of the government (central and regional), so that required coordination and commitment together to deal with poverty and improve equity. Therefore the policy of West Java Province needs to prioritize efforts to increase funding through funding synergy with the central and district/city governments in order to finance a comprehensive and broader poverty reduction program. The policy is seen as a set of actions, frameworks, guidelines, plans, maps or strategies designed to translate the political vision of government or government agencies into programs and actions to achieve certain goals in the field of social welfare (Suharto, 2008). The social policy deals with issues of social and welfare issues as wellbeing in social services by the state. Social service as the embodiment of the country's ideals, established for the welfare of the people. Based on the above description, the researcher defines the research problem "How to describe poverty and West Java Provincial Government Policy in Poverty Alleviation". The purpose of this study to describe the poverty and policy of West Java Provincial Government in Poverty Eradication. Through this research is expected to contribute to the improvement of policies in poverty reduction to achieve the condition of the people of West Java more prosperous.

\section{Method}

The design of this study using Qualitative Descriptive. The informants involved in this study are the Civil State Apparatus of each of the 2 persons who can represent the Organization of Regional Devices at the West Java Provincial level such as from Bappeda (Development Planning Agency at SubNational Level), Dinas Social (Social Services), KUKM (Small and Medium Business Group) and Community Empowerment Agency, Civil Registry Offices and district/city representatives in 5 districts/cities such as Tasikmalaya City, Tasikmalaya District, Ciamis, Cirebon City, Cirebon District, Majalengka and Indramayu. A total number of informants are 20 peoples. Data collection technique is conducted by interview, focus group discussion and documentation study. FGDs were conducted at the provincial level in West Java twice and at the district /city level twice. Validation of data is done by using triangulation from various primary data sources with various informants and secondary from various study results and data available in various Organization of the Region. 


\section{Literature Review}

\section{Social Welfare Approach}

According to Romanyshyn and Romamyshyn (in Dubois \& Milley (1992,) social welfare: [...] includes those provisions and processes that are concerned with the treatment and prevention of social problems, the development of human resources, and the improvement of the quality of life. It involves social services to individuals and families as well as efforts to strengthen or modify social institutions. Social welfare functions to maintain the social system and to adapt it to change social reality.

The elements of social welfare can be used as a benchmark to measure the level of welfare of a community. According to Bell in Dubois \& Milley (1992), ideally, social welfare should be able to respond quickly and appropriately to human needs such as providing adequate income security, adequate housing, cheap education, affordable health care, and security for the individual -personal, and high public participation in community activities. Such services should be effective, fair, appropriate, feasible and up to date. To ensure this, there is a need for regular planning mechanisms, professional social accounting, appropriate feedback and close coordination between economic policies.

In responding to the needs of society as an effort to improve social welfare, there are two different views on social welfare, namely residual and institutional views. The residual view holds that social welfare is a residual activity, namely that social welfare services work when problems occur in a family, economic and political structures. So a troubled society can take advantage of social welfare services. Instead, the institutional view considers social welfare the right of every citizen. This means the social welfare system must be available under any circumstances, available to all citizens and integrated as one of the state systems. Zastrow (2000) provides a response to this view which explains that residual views perceive social welfare services lead to dependence on the recipients of their services and will ultimately have a negative impact on the country's economy. Instead, the institutional view considers social welfare services programs necessary to help meet basic human needs. The discourse on social welfare from these two different views is mediated by a developmental view. Developmental perspectives advocate for social interventions that can contribute positively to economic development, promoting harmony between economic and social institutions.

Frankel in Siporin (1975) states that welfare is a moral idea to achieve a good life and good society. Therefore, there must be a think and build a social welfare system adequate for community life, which includes forms of social intervention that can be categorized 1) Planning and Analysis of Social Welfare Policy; 2) Social Welfare Administration. 3) Maintenance or Improvement Programs of Income; 4) Social services; 5) Social Action.

\section{Social Welfare Policy}

Particularly related to this paper will only examine more deeply on aspects of social welfare policy analysis that can further be used to formulate plans in various social welfare development programs. Social engineering helps in formulating and consolidating government and non-governmental plans, policies, and programs such as social security systems, income insurance, employment law, local welfare councils and welfare funds.

Various policies in the field of social welfare relate to the provision of financial guarantees. Policies related to the provision of social services consist of activities tailored to individual needs, direct, organized, case interventions aimed at assisting individuals, collectives, and the social environment so that they can reciprocally adapt to each other. Forms of social service are; a) access services, such as information, referrals, advocacy, and participation; b) therapy, relief, and rehabilitation, including social protection and replacement care, c) socialization and development services. To achieve an adequate level of social welfare there must be an effort to build an adequate social welfare system. When viewed from an institutional point of view this is the responsibility of the government. 
Therefore, the central and local governments need to formulate the arrangements of the rules in the formulation of social welfare development policies.

\section{Results}

\section{Poverty Overview}

The population below the Poverty Line in West Java experienced an increase of 196,739 people $(0.36$ percent), from 4,238,960 people (9.18 percent) in September 2014 to 4,435,699 people ( 9.53 percent) in March 2015. The Poverty Depth Index rose from 1,393 in September 2014 to 1,628 in March 2015. The Poverty Severity Index showed an increase from 0.332 in September 2014 to 0.435 in March 2015. This indicates that the average spending of the poor tends to move further away from the poverty line and inequality of spending the poor also tend to widen. (http://pusdalisbang.jabarprov.go.id/pusdalisbang/beritastatistik-80.html). With such data, West Java is still facing the problem of poverty that is still severe. This poverty phenomenon can lead to an increase in the number of social welfare problems. In 2014 the number of people classified as the poor is $1,821,049$ inhabitants. Women's socioeconomic groups are increasing in number each year (ranging from 210,000 to 299,000 in the period 2009 to 2014). West Java also faces quite serious problems related to the group of poor non-permanent residents (homeless, beggars and scavengers) that reached 50,000 by 2014 , in which there were migration problems. The number of neglected elderly in West Java reaches 213,054 in 2014. Child protection issues covering neglected toddlers, neglected children, street children, children with disabilities, children victims of violence and children who need special protection in 2014 number more than 160 thousand children ( $70 \%$ of the total).

\section{Poverty Reduction Policy}

Currently, there are at least 26 national laws and regulations that are directly related to social welfare. This is sufficient and comprehensive to be the foundation and support of social welfare development. Some West Java provincial regulations have also regulated the implementation of social welfare programs such as the MDGs Acceleration Action Plan, the Determination of Minimum Service Standards for Social Affairs, Corporate Social and Environmental Responsibility, and the Prevention and Handling of Victims of Trafficking in Persons. West Java is even the only province that has the Perda of Family Development Development (No. 9 of 2014). The establishment of the Family Resilience Regulation is based on the consideration of the importance of increasing family resilience to prevent the spread of various social problems (eg drugs, psychological problem families, street children, neglect and violence against children, children in conflict with law, family poverty) caused by family malfunction through development of government and community participation. The basis for the implementation of social welfare in West Java has been established West Java Provincial Regulation No. 30 of 2012 on the Implementation of Social Welfare. District/City Government is responsible for the implementation of the social welfare business. This rule refers to the Regional Autonomy Policy for Social Welfare in accordance with the regional authority in the implementation of Law no. 23 years 2014. At the provincial and local levels (cities and districts) still needed various regulations. For example, arrangements on the handling of social problems with cross-border areas with other areas outside West Java, especially for the handling of poor and non-permanent residents. Policies on family resilience at the district and city levels also need to be developed and effectiveness in the implementation given the importance of family resilience in preventing and addressing various risk factors that can cause social problems. Legislation as a form of policy that supports social welfare not only must be held but also must be implemented optimally. Various policies at the central and regional levels in West Java have provided a foundation and encourage collaboration and synergy between government, society, business and universities in accelerating the achievement of social welfare, especially in poverty alleviation and improving the quality of disadvantaged communities. For example in 2015, MOU has agreed between the Government of West Java Province and 22 private companies in an effort to accelerate social welfare in the region of West Java. Nevertheless, the implementation of policies that facilitate synergy between communities, government, universities and the business world has not been widely implemented and concentration on infrastructure issues of 
PUSKESMAS and schools. So it has not been in the intervention of the more massive problem of poverty.

Regulation of the Minister of Social Affairs No. 129/HUK/2008 on SPM Social Area of Province, Regency/Municipality and Minister of Social Affairs Decree Number 80/HUK/2010 concerning Guide of Planning of Financing of SPM Achievement in Social Area Provincial and District/City Region has been followed up by Governor of Java-West no. 55 of 2012 on Implementation of Minimum Service Standards Social Sector in West Java Province. But in its implementation still not oriented to the achievement of targets that have been set in the attachment of the SPM.

Efforts to break the poverty chain is a necessary commitment of the political will with a professional approach and adequate budget determination. Standardized standards that integrate social protection, social services, and social assistance programs are inevitable for people with poverty-related social welfare issues, such as various forms of abandonment and poverty. Thus, the wider volume coverage for Social Welfare Persons is also the responsibility of the West Java government as well as the districts/municipal governments that are still limited.

\section{Conclusions}

Social welfare planning and policy is the foundation for the implementation of social welfare development which is mainly carried out by the government with the support of community, business, and universities. Social welfare planning and policy is not just a complement to development planning and policy framework but an integrative, priority and substantive element to be implemented.

Poverty alleviation regulations and policies relating to other social issues are limited in terms of budget and program integration in the areas of social assistance, community empowerment, social services and social protection.

Regulation at the central level is sufficient, but local governments have not been fully able to describe and operationalize with various regulations either at the level of Perda, Governor Regulation, Mayor Regulation or Bupati Regulation.

\section{Recommendation}

The handling of poverty needs to be strengthened by expanding the scope of social services, social empowerment, and social protection both in quantity and quality of handling.

Development of social welfare planning and policy development that is anticipative and evidencebased and participatory and transparent.

Strengthening the implementation of existing laws and regulations so that more applicable

Harmonization of legislation and policies across the organization of regional apparatus at the level of provincial and district government in handling social welfare issues.

Four Poverty Reduction Strategies: (a) Creation opportunities, (b) People empowerment, (c) Improved capacity, (d) Social protection ( 'social protection').

\section{References}

Pusdalisbang Jawa Province. 2015

BAPPENAS RI. 2016

Dubois, S \& Milley K, 1995, Social Work: An Empowering, Wadsworth Thomson Learning, Canada. 
Frankel and Siporin, 1975, Introduction to Social Work, McManila Publisher, London.

Suharto, Edi. 2008, Social Policy as a Public Policy. Alfabeta, Bandung.

Zastrow, C, 2000, Social Problem Issues an Solution, Wadsworth Thomson Learning, Canada.

West Java Provincial Regulation No. 2 of 2013 on Corporate Social and Environmental Responsibility Guidelines and Partnership and Community Development Program in West Java

West Java Provincial Regulation No. 10 of 2012 on the Implementation of Social Welfare

West Java Governor Regulation no. 55 of 2012 on the Implementation of Minimum Service Standards Social Sector in the Province of West Java.

West Java Provincial Regulation no. 25 The year 2010 concerning Long-Term Development Plan of the Year 2005-2025.

The year 2011 has been published by Governor Regulation No.56 Year 2011 West Java Provincial News No. 55 Series E October 31, 2011, on the Regional Action Plan for Acceleration of Achieving MDGs Target West Java Province

West Java Governor Regulation number: 30 of 2011 on Facilitation of Corporate Social Responsibility and Environment in West Java

West Java Governor Regulation No. 9 of 2010 on Guidelines for Implementation of Regional Regulation Number 5 the Year 2006 on Child Protection. 